\title{
DEPDC1 Gene
}

National Cancer Institute

\section{Source}

National Cancer Institute. DEPDC1 Gene. NCI Thesaurus. Code C126129.

This gene is involved in the negative regulation of gene transcription. 